\title{
Replacing oat hay with coffee husk in the feed of finishing lambs
}

\section{A casca de café em substituição ao feno de aveia na alimentação de cordeiros em terminação}

\author{
Lais Belan ${ }^{1}$; Fabíola Cristine de Almeida Rego ${ }^{2 *}$; Filipe Alexandre Boscaro \\ de Castro $^{3}$; Camila Cano Serafim ${ }^{4}$; Marta Juliane Gasparini ${ }^{4}$; Marilice Zundt ${ }^{5}$; \\ Agostinho Ludovico ${ }^{6}$; Caliê Castilho ${ }^{5}$; Luiz Fernando Coelho Cunha Filho'; \\ Josiane Ito Eleodoro 4
}

\begin{abstract}
The objective of this study was to evaluate the efficacy of replacing oat hay with coffee husk for the feeding of confined lambs. In this study, 24 male Texel lambs of approximately 60 days of age and with a mean \pm standard error weight of $21.95 \pm 5.81 \mathrm{~kg}$ were examined. Their diet was composed of $30 \%$ oat hay and $70 \%$ concentrated feed per kilogram of dry matter. The experimental design was randomized and included four treatments $(0,7.5,15$, and $22.5 \%$ of coffee husk in the total dry matter), with six replicates of each treatment. The animals were slaughtered when they reached a mean live weight of 32 $\mathrm{kg}$. There was no significant difference in dry matter intake and mean daily weight gain (which were $197 \mathrm{~g} \mathrm{day}^{-1}$ ) among treatments. The mean daily weight gain (DWG) was not significantly affected (P $>0.05$ ) by the replacement of oat hay with coffee husk in the diet, with the overall mean DWG being $215.05 \mathrm{~g} \mathrm{day}^{-1}$. There were no significant differences $(\mathrm{P}>0.05)$ among treatments in any of the studied carcass variables, and the mean true carcass yield was $53.9 \%$. The lambs presented a mean finishing score of 2.96 (on a scale of 1 to 5) and a conformation of 4.21 (on a scale of 1 to 6), characterizing them as good carcasses. In terms of economic viability, the $7.5 \%$ diet stood out as the one that had the highest profitability, generating a profit of $\$ 3.25$ USD per $\mathrm{kg}$ of carcass produced. Coffee husk can therefore replace oat hay in the feed of finishing lambs in concentrations of 0.075 to $0.225 \mathrm{~kg} \mathrm{~kg}^{-1}$ of total dry matter with biological and economical efficacy and generating good commercial carcasses.
\end{abstract}

Key words: Byproduct. Economic viability. Morphometric measurements. Sheep. Weight gain.

\section{Resumo}

O objetivo deste estudo foi avaliar a eficácia da substituição do feno de aveia pela casca de café na alimentação de cordeiros confinados. Foram utilizados 24 cordeiros machos da raça Texel, com

\footnotetext{
Prof. M.e, Curso de Medicina Veterinária, Universidade Norte do Paraná, Pitágoras UNOPAR, Londrina, PR, Brasil. E-mail: laisbelan@gmail.com

2 Profs. Drs., Curso de Mestrado em Saúde e Produção Animal, Pitágoras UNOPAR, Arapongas, PR, Brasil. E-mail: fabiola. cristine@kroton.com.br; luiz.cunha@unopar.br

3 Prof. Dr., Curso de Zootecnia, Universidade Estadual de Londrina, UEL, Londrina, PR, Brasil. E-mail: fabcastro76@yahoo.com.br

4 Discentes, Curso de Mestrado do Programa de Pós-Graduação em Saúde e Produção de Ruminantes, Pitágoras UNOPAR, Arapongas, PR, Brasil. E-mail: camilacanoserafim@hotmail.com; josiane_ito@outlook.com; martajuliane@hotmail.com

5 Profs. Drs., Programa de Pós-Graduação em Ciência Animal, Universidade do Oeste Paulista, UNOESTE, Presidente Prudente, SP, Brasil.E-mail: mari@unoeste.br; calie@unoeste.br

6 Prof. Dr., Curso de Mestrado em Ciência e Tecnologia do Leite e Derivados, Pitágoras UNOPAR, Londrina, PR, Brasil. E-mail: agostinho@rocketmail.com

* Author for correspondence
} 
aproximadamente 60 dias de idade e pesando em média $(21,95 \mathrm{~kg} \pm 5,81)$. As rações foram compostas por $30 \%$ de feno de Aveia e $70 \%$ de concentrado por $\mathrm{kg}$ de matéria seca. O delineamento experimental foi inteiramente casualizado com quatro tratamentos $(0 ; 7,5 ; 15$ e $22,5 \%$ de casca de café na matéria seca total da dieta) e seis repetições. $\mathrm{O}$ abate dos animais foi realizado quando atingiram a média de 32 $\mathrm{kg}$ de peso vivo. Não foram observadas variações no consumo de nutrientes, assim como no ganho de peso médio diário (197 $\left.\mathrm{g} \mathrm{dia}^{-1}\right)$. O ganho de peso médio diário (GPD) não foi alterado $(\mathrm{P}>0,05)$ com a substituição do feno de aveia pela casca de café na dieta, ficando com média de $215,05 \mathrm{~g} \mathrm{dia}^{-1}$. Não houve diferença $(\mathrm{P}>0,05)$ para nenhuma das variáveis de carcaça estudadas e o rendimento verdadeiro da carcaça foi em média 53,9\%. Os cordeiros apresentaram média de 2,96 para grau de acabamento (escala de 1 a 5) e 4,21 de conformação, caracterizando boas carcaças. Com relação à viabilidade econômica, a dieta com $0,075 \mathrm{~kg}$ de casca de café teve destaque em lucratividade, gerando 3,25 U\$ de lucro por kg de carcaça produzida. A casca de café pode substituir o feno de aveia na terminação de cordeiros, em teores de 7,5 a 22,5\% da matéria seca total da dieta com eficácia biológica e econômica, gerando boas carcaças para a comercialização.

Palavras-chave: Coproduto. Ganho de peso. Medidas morfométricas. Ovinos. Viabilidade econômica.

\section{Introduction}

The confinement of finishing lambs has been increasingly practiced by sheep producers in recent years. This production system results in the slaughter of younger animals, carcass standardization, availability of quality meat in the off season, faster return on invested capital (CARVALHO et al., 2007), and reduced mortality rates (MACEDO et al., 2000), in addition to providing pastures for other herd categories. However, confinement requires greater investment by the producer. Increased production costs, especially those related to animal feed, can compromise profits and system profitability. Thus, many studies with the objective of enabling nutrition with high production rates and reduced costs have been conducted, including those testing the replacement of part of the diet with agroindustrial byproducts (FARIAS et al., 2012).

Coffee husk is a byproduct available in several Brazilian states, such as Minas Gerais, Espírito Santo, São Paulo, Paraná, Bahia, Rondônia, Mato Grosso, and Goiás, among others. Brazil is the world's leading coffee producer, followed by Vietnam, Colombia, and Indonesia, with its production reaching 2.6 million tons in 2015 (ABIC, 2018). Brazil and Vietnam account for $50 \%$ of the world's coffee production.

According to Dias et al. (2012), coffee processing generates waste that represents approximately $50 \%$ of the weight harvested. This waste is a low-cost raw material, but if not disposed of properly it can be an environmental pollutant. A few studies on using coffee husk in the diet of lambs did not show changes in their feed intake (SOUZA et al., 2004) or their performance and carcass quality (GARCIA et al., 2000), confirming its potential use in feeding ruminants.

Considering the volume of coffee husk produced annually in Brazil, the need to use this byproduct rationally, and the lack of research on its use in lamb feeding, the present study aimed to verify whether the replacement of oat hay with coffee husk could be effectively used in the feeding of confined finishing lambs.

\section{Materials and Methods}

The experiment was conducted at Norte do Paraná University/UNOPAR, Arapongas Campus, from October to December. This study followed ethical principles of animal experimentation and was approved by the Animal Ethics Committees of UNOPAR (CEUA 012/13). Laboratory tests were analyzed at the Bromatology laboratory and at the Diagnostic Center of Veterinary Medicine (UNOPAR, Arapongas Campus).

At the beginning of the experiment, the animals were identified, weighed, and dewormed. This study 
included 24 intact Texel lambs of approximately 90 days of age and with a mean \pm standard error weight of $21.95 \pm 4.27 \mathrm{~kg}$ at the beginning of the adaptation period. The lambs were kept in a confinement system for 45 days, which was preceded by 7 days of adaptation to experimental conditions.
The following levels of coffee husk inclusion to replace oat hay were tested, forming four different experimental diets: $0,7.5,15$, and $22.5 \%$ coffee husk replacing oat hay, based on the total dry matter (DM) in the diet (Table 1).

Table 1. Composition of the experimental diets $\left(\mathrm{g} \mathrm{kg}^{-1}\right.$ of DM) containing different levels of coffee husk to replace oat hay.

\begin{tabular}{ccccc}
\hline & \multicolumn{4}{c}{ Coffee husk replacing oat hay (\%) } \\
\hline Ingredients & 0 & 7.5 & 15 & 22.5 \\
Oat hay & 300.0 & 225.0 & 150.0 & 75.0 \\
Coffee husk & 00.0 & 75.0 & 150.0 & 225.0 \\
Crushed corn & 476.5 & 467.9 & 459.4 & 450.8 \\
Soybean meal & 182.5 & 191.1 & 199.6 & 208.2 \\
Mineral & 23.0 & 23.0 & 23.0 & 23.0 \\
Calcitic limestone & 14.0 & 14.0 & 14.0 & 14.0 \\
Salt & 4.0 & 4.0 & 4.0 & 4.0 \\
\hline Nutritional components & & & & 932.1 \\
Dry matter & 920.9 & 934.8 & 738.4 & 67.7 \\
Mineral matter & 80.8 & 57.5 & 151.1 \\
Crude protein & 145.0 & 148.4 & 152.0 & 19.6 \\
Ethereal extract & 23.5 & 25.0 & 28.8 & 329.5 \\
Neutral detergent fiber & 176.2 & 241.8 & 176.7 & 191.2 \\
Acid detergent fiber & 89.6 & 136.7 & 738.4 & 722.9 \\
Total digestible nutrients & & 754.0 & & \\
\hline
\end{tabular}

${ }^{1}$ Guarantee levels for every 1,000 g: calcium (minimum), $195 \mathrm{~g}$; calcium (maximum), $205 \mathrm{~g}$; phosphorus (minimum), $68 \mathrm{~g}$; magnesium (minimum), $6 \mathrm{~g}$; sulfur (minimum), $30 \mathrm{~g}$; sodium (minimum), $133 \mathrm{~g}$; cobalt (minimum), 60 mg; selenium (minimum), $24 \mathrm{mg}$; manganese (minimum) $3 \mathrm{~g}$; iodine (minimum), $90 \mathrm{mg}$; fluorine (maximum), $680 \mathrm{mg}$; zinc (minimum) 4,500 mg.

${ }^{2}$ Total digestible nutrients (TDN) were estimated according to Cappelle et al. (2001).

The experimental design was completely randomized, with 24 animals randomly distributed among four $8 \mathrm{~m}^{2}$ bays that were roofed and had cemented floors, drinking fountains, and cement troughs (30 linear $\mathrm{cm}$ per animal). For additional comfort, the floor was always covered with a sawdust bed, which was changed and conserved as needed.

The feed was formulated to meet the nutritional requirements of lambs with $20 \mathrm{~kg}$ of body weight for a gain of $200 \mathrm{~g} \mathrm{day}^{-1}$ (NRC, 2007). This was an isoproteic diet, so the contents of corn and soybean meal were adjusted according to the inclusion of coffee husk, always keeping a ratio of bulk:concentrate of 30:70 (Table 1). All experimental feeds contained 15 ppm of monensin sodium. The techniques described by Mizubuti et al. (2009) were used to determine the chemical composition of the diet (Table 1). The content of total digestible nutrients (TDN) was estimated according to Cappelle et al. (2001). 
The feed was formulated based on the bromatological composition of the ingredients used (Table 2). Feeding times were $8 \mathrm{~h} 00$ and $17 \mathrm{~h} 00$. Leftover feed was weighed daily, and the amount provided was adjusted according to the previous day's intake to allow there to be leftovers of $15 \%$ of the total DM offered. The animals had unrestricted access to water.
The lambs were weighed at the beginning and end of the adaptation period, which coincided with the beginning of the experimental period, and this weight was called the initial live weight. They were then subsequently weighed every 13 days, always at the same time, before being fed in the morning.

Table 2. Productive performance of confined lambs fed on diets with coffee husk replacing oat hay.

\begin{tabular}{lccccccc}
\hline \multirow{2}{*}{\multicolumn{1}{c}{ Variable }} & \multicolumn{9}{c}{ Coffee husk replacing oat hay $(\%)$} & \multirow{2}{*}{ Mean } & P & CV (\%) \\
\cline { 2 - 5 } & 0 & 7.5 & 15 & 22.5 & & & \\
\hline Initial live weight $(\mathrm{kg})$ & 22.7 & 22.8 & 23.3 & 23.2 & 23.0 & 0.99 & 21.87 \\
Final live weight $(\mathrm{kg})$ & 31.7 & 31.0 & 33.1 & 31.6 & 31.8 & 0.96 & 18.28 \\
MDWG per animal $\left(\mathrm{g} \mathrm{day}^{-1}\right)$ & 200.0 & 184.0 & 218.0 & 187.0 & 197.0 & 0.77 & 28.86 \\
* Batch consumption $\left(\mathrm{kg} \mathrm{day}^{-1}\right)$ & 6.54 & 6.54 & 6.36 & 6.30 & 6.42 & 0.35 & 12.48 \\
* Batch DM consumption $(\% \mathrm{LW})$ & 3.96 & 4.05 & 4.00 & 3.97 & 4.00 & 0.70 & 10.11 \\
\hline
\end{tabular}

MDWG: mean daily weight gain; $\mathrm{P}$ : probability of significance; $\mathrm{CV}$ : coefficient of variation.

*Lot of six animals.

All animals were slaughtered in a slaughterhouse on the same day at which they reached an average final live weight (FLW) of $32 \mathrm{~kg}$. The animals were stunned by electronarcosis and slaughtered in accordance with humane slaughtering standards. Before slaughter, the animals were fasted for 16 hours and were then weighed again to obtain their body weight at slaughter (BWS). The feet, head, and internal organs were removed after slaughter, and then the carcass was weighed to obtain the hot carcass weight (HCW). Subsequently the carcasses were left in a cold room at $4{ }^{\circ} \mathrm{C}$ for 24 hours. After cooling, the carcasses were weighed to obtain the cold carcass weight (CCW). Hot (HCY) and cold (CCY) carcass yields were determined based on the percentage of the FLW represented by the hot and cold carcass weights, respectively. The gastrointestinal tract was also removed at slaughter and emptied, and its contents were weighed to obtain the empty body weight (EBW) and determine the biological or true carcass yield (TY), where: EBW $=$ FLW - gastrointestinal content; $\mathrm{TY}=(\mathrm{HCW} /$
EBW) $\times 100$; and the cooling loss (CL) was $\mathrm{CL}=$ $[(\mathrm{HCW}-\mathrm{CCW}) \times 100] / \mathrm{HCW}($ SILVA SOBRINHO; OSÓRIO, 2008).

Subsequently, the following morphological measurements of the carcasses were taken: external carcass length, rump width, croup perimeter, maximum thorax width, leg perimeter, arm perimeter, arm width, and back width (OSÓRIO; OSÓRIO, 2005). Carcass conformation (6 = superior, $5=$ excellent, $4=$ very good, $3=$ good, 2 = normal, 1 = poor.) and finishing degree [from 1 (absent fat cover) to 5 (abundant fat cover) were evaluated using photographic standards (CAÑEQUE; SAÑUDO, 2000).

After carcass cooling, the longissimus dorsi muscle was removed through a cross section between the $12^{\text {th }}$ and $13^{\text {th }}$ ribs to determine the loin eye area (LEA) and subcutaneous fat thickness (CEZAR; SOUZA, 2007).

Feed costs were calculated according to the average dollar price ( $\mathrm{R} \$ 2.25)$ of different feed 
components converted to US\$ at the time of the experiment as follows: oat hay DM, US\$ $0.19 \mathrm{~kg}^{-}$ '; coffee husk, US\$ $0.03 \mathrm{~kg}^{-1}$; corn, US\$ $0.23 \mathrm{~kg}$ 1; soybean meal, US\$ $0.57 \mathrm{~kg}^{-1}$; mineral mix, US\$ $1.00 \mathrm{~kg}^{-1}$; calcitic limestone, US\$ $0.23 \mathrm{~kg}^{-1}$; and white salt, US\$ $0.18 \mathrm{~kg}^{-1}$. The lean lamb acquisition cost considered the initial price paid for each lamb, which was US\$2.66 $\mathrm{kg}^{-1}$ of live weight. The total cost was calculated by adding up the costs of food, transportation, and slaughter. The gross revenue was determined as the sale value of the carcass (US\$ $8.00 \mathrm{~kg}^{-1}$ ) multiplied by the mean carcass weight. The gross margin was the difference between the gross revenue and total cost.

The data were submitted to tests to determine whether they had homogenous variances and their residuals followed a normal distribution, which were then followed by analyses of variance (ANOVAs). When ANOVA results were significant $(\mathrm{P}<0.05)$, the data were submitted to regression analysis, with the level of coffee husk inclusion used to replace oat hay in the feed as the independent variable.

\section{Results and Discussion}

The animals entered confinement with a mean weight of $23.0 \mathrm{~kg}$, and stayed there until they reached a mean weight of $31.80 \mathrm{~kg}$. The mean DWG (Table 2) was within the expected range for the feed used, since, according to the NRC (2007), animals in early stages of development require a feed with $0.79 \mathrm{~kg} \mathrm{~kg}^{-1}$ of TDN to gain $200 \mathrm{~g}^{\text {day }}{ }^{-1}$.

There has been great variability in the performance results of previous studies that used the breed used in this one, mainly because of animal genetics and the energetic levels of the diets used. The gains observed in the present study (Table 2) were close to the results of a study by Garcia et al. (2000), who used diets containing 15\% coffee husk and obtained gains of $193 \mathrm{~g}$ day $^{-1}$ in crossbred
Texel, Bergamasca, and Santa Inês lambs. The performance of the lambs in this present study was a little lower than the results obtained by Carvalho et al. (2005), since that study achieved gains of $274 \mathrm{~g}$ day $^{-1}$ for Texel lambs in post-weaning confinement, $335 \mathrm{~g} \mathrm{day}^{-1}$ for crossbred Texel and Suffolk lambs, and $305 \mathrm{~g} \mathrm{day}^{-1}$ for Suffolk lambs, all when using diets with $0.70 \mathrm{~kg} \mathrm{~kg}^{-1}$ of TDN.

In addition, the inclusion of coffee husk in the diet of finishing lambs did not result in any significant differences $(\mathrm{P}>0.05)$ in their daily dry matter intake. The batch mean was $6.42 \mathrm{~kg} \mathrm{day}^{-1}$ and $4 \%$ of live weight (Table 2), which represents an intake of $1.07 \mathrm{~kg} \mathrm{day}^{-1}$ per animal. These values are above the ones recommended by the NRC (2007) for lambs with a $20 \mathrm{~kg} \mathrm{LW}$ and gains of $200 \mathrm{~g} \mathrm{day}^{-1}$, which would demand an intake of $0.59 \mathrm{~kg}$ of DM and represent $2.97 \%$ of live weight.

The increased use of coffee husk as a replacement for oat hay increased NDF and ADF levels in the diet and decreased the proportions of EE and NFC (Table 1), which together led to a decreased TDN in the feed. However, the MDWG was similar ( $\mathrm{P}>$ 0.05 ) for all animals, regardless of their diet.

There were no significant differences $(\mathrm{P}>0.05)$ in any of the carcass variables studied (Table 3), which may have been due to the animals all having similar weights at slaughter (mean of $31.8 \mathrm{~kg}$ ). The carcass yields (hot, cold, and true) in this study were all within the standard ranges found in the literature (OLIVEIRA et al., 2017; Almeida et al., 2015), and did not vary among the different levels of coffee husk inclusion used to replace hay in the diet. The quality of coffee husk should be highlighted in terms of these results, since its inclusion did not change any of the production indices. The yields presented herein were also within the range (40 to $50 \%$ ) described by Silva Sobrinho (2001) for meat sheep breeds. 
Table 3. Carcass variables for confined lambs fed on diets with coffee husk replacing oat hay.

\begin{tabular}{|c|c|c|c|c|c|c|c|}
\hline \multirow{2}{*}{ Variable } & \multicolumn{4}{|c|}{ Coffee husk replacing oat hay (\%) } & \multirow{2}{*}{ Mean } & \multirow{2}{*}{$\mathrm{P}$} & \multirow{2}{*}{$\mathrm{CV}(\%)$} \\
\hline & 0 & 7.5 & 15 & 22.5 & & & \\
\hline Hot carcass weight (kg) & 15.8 & 16.2 & 15.2 & 14.0 & 15.3 & 0.50 & 17.20 \\
\hline Cold carcass weight (kg) & 15.0 & 15.7 & 14.7 & 13.5 & 14.8 & 0.51 & 17.32 \\
\hline Hot carcass yield $(\%)$ & 50.8 & 52.3 & 46.5 & 45.0 & 48.7 & 0.33 & 15.48 \\
\hline Cold carcass yield (\%) & 48.5 & 50.8 & 45.0 & 43.5 & 47.0 & 0.34 & 15.85 \\
\hline True yield (\%) & 55.7 & 58.6 & 51.5 & 49.5 & 53.9 & 0.26 & 15.23 \\
\hline Cooling loss $(\%)$ & 3.05 & 2.79 & 3.28 & 3.37 & 3.12 & 0.65 & 26.88 \\
\hline
\end{tabular}

P: probability of significance; $\mathrm{CV}$ : coefficient of variation.

There were no significant differences $(\mathrm{P}>0.05)$ in any of the carcass morphometric measurements examined (Table 4), demonstrating the genetic similarity of the animals used and the lack of differences among each diet. The mean external carcass length was $53.7 \mathrm{~cm}$. Croup, leg, and arm perimeters had mean values of 57.2, 35.6, and 18.9 $\mathrm{cm}$, respectively. Thoracic, dorsum, and croup widths had mean values of $21.3,16.6$, and $18.9 \mathrm{~cm}$, respectively. The mean arm width was $6.9 \mathrm{~cm}$.

Table 4. Morphometric carcass measurements of confined finishing lambs fed on diets with coffee husk replacing oat hay.

\begin{tabular}{|c|c|c|c|c|c|c|c|}
\hline \multirow{2}{*}{$\begin{array}{c}\text { Morphometric } \\
\text { measurement }(\mathrm{cm})\end{array}$} & \multicolumn{4}{|c|}{ Coffee husk replacing oat hay (\%) } & \multirow{2}{*}{ Mean } & \multirow{2}{*}{$\mathrm{P}$} & \multirow{2}{*}{$\mathrm{CV}(\%)$} \\
\hline & 0 & 7.5 & 15 & 22.5 & & & \\
\hline External length & 54.2 & 53.7 & 53.6 & 53.3 & 53.7 & 0.98 & 7.13 \\
\hline Rump perimeter & 57.0 & 59.0 & 56.8 & 55.8 & 57.2 & 0.49 & 6.21 \\
\hline Leg perimeter & 36.2 & 37.3 & 35.0 & 33.7 & 35.6 & 0.83 & 20.09 \\
\hline Arm perimeter & 19.0 & 19.2 & 18.8 & 18.8 & 19.0 & 0.92 & 5.48 \\
\hline Thoracic width & 20.7 & 22.3 & 21.8 & 20.5 & 21.3 & 0.41 & 9.96 \\
\hline Back width & 17.4 & 16.4 & 16.8 & 16.0 & 16.7 & 0.43 & 8.82 \\
\hline Rump width & 19.2 & 19.5 & 19.1 & 18.0 & 18.9 & 0.21 & 6.53 \\
\hline Arm width & 7.1 & 6.9 & 6.9 & 6.8 & 6.9 & 0.91 & 10.21 \\
\hline
\end{tabular}

P: probability of significance; $\mathrm{CV}$ : coefficient of variation.

The mean CL was thus $3.12 \%$, which is within the acceptable range of 3.0 to $4.0 \%$ for sheep described by Sañudo et al. (1981). According to Silva Sobrinho et al. (2005), carcasses with lower fat cover could have greater cooling losses. However, in the present study there was no fat cover difference among the finishing animals (Table 5). In a study with male lambs slaughtered with a mean final weight of 34 $\mathrm{kg}$, Oliveira et al. (2017) found a similar CL value to ours $(3.11 \%)$, which they reported to be within the normal range. 
Table 5. Carcass variables for confined finishing lambs fed on diets with coffee husk replacing oat hay.

\begin{tabular}{ccccccccc}
\hline \multirow{2}{*}{ Variable } & \multicolumn{9}{c}{ Coffee husk replacing oat hay (\%) } & \multirow{2}{*}{ Mean } & P & CV (\%) \\
\cline { 2 - 5 } & 0 & 7.5 & 15 & 22.5 & & & \\
\hline Finishing (1 to 5) & 3.00 & 3.50 & 3.00 & 2.33 & 2.96 & 0.19 & 29.89 \\
Conformation (1 to 6) & 4.00 & 4.67 & 4.20 & 4.00 & 4.21 & 0.65 & 24.41 \\
Loin eye area ( $\left.\mathrm{cm}^{2}\right)$ & 14.57 & 14.58 & 13.81 & 13.89 & 14.23 & 0.93 & 18.29 \\
Subcutaneous fat thickness (mm) & 1.48 & 1.19 & 1.30 & 1.26 & 1.31 & 0.39 & 26.30 \\
\hline
\end{tabular}

P: probability of significance; $\mathrm{CV}$ : coefficient of variation.

The inclusion of coffee husk replacing oat hay in up to $22.5 \%$ of the dry matter did not significantly change $(\mathrm{P}>0.05)$ the degree of finishing, conformation, LEA, or subcutaneous fat thickness, and thus produced standardized carcasses (Table 5). The diet was isoproteic and variations in levels of other nutrients (TDN, EE, NDF, and ADF) were not enough to affect animal finishing. Variations in nutritional levels normally do not lead to qualitative or quantitative variations in carcass characteristics. Because of this, a previous study that evaluated energetic levels in finishing lamb diets did not report LEA differences (GARCIA et al., 2003) in Suffolk sheep. Similarly, Pires et al. (2006) did not find differences in fat thickness and LEA among lambs fed diets with different NDF levels. On the other hand, a study on cotton seed levels in diets presenting 29 to $90 \mathrm{~g} \mathrm{~kg}^{-1}$ of EE also showed no changes in finishing, LEA, and carcass fat thickness (CUNHA et al., 2008). EE variations also occurred in the diet used in the present study, and did not result in variation in carcass finishing and fat thickness.

Lambs fed diets containing different percentages of coffee husk presented a mean finishing grade of 2.96 (on a scale from 1 to 5 ) and a mean conformation of 4.21 (on a scale from 1 to 6) (Table 5), indicating good levels of carcass fat (FISHER, 1990) and optimal conformation (OSÓRIO et al., 2013). In this study, conformation varied between 4.00 and 4.67, showing a dominance of convex profiles, which indicates that the carcasses presented good conformation, with short, wide, and compact shapes.
Another possible explanation for the similarities in fat variables (fat thickness and finishing degree) observed is that the animals were slaughtered at an early age (between 4 to 6 months) and at the same time for all treatments. The distribution of fat in the carcass is known to be uniform among the different points of fat deposition in the animal, and fat deposits increase in size as the animal gains weight (JOHNSON et al., 1972). This was also found in the present study, wherein the animals presented the same weight gain and were slaughtered on the same day, with the same age, and with similar fat deposits.

According to the classification proposed by Silva Sobrinho (2001), the mean carcass thickness observed in the present study $(1.31 \mathrm{~mm})$ is small (1 to $2 \mathrm{~mm}$ ), indicating that the carcasses contained a small amount of fat, since there is a positive correlation between fat thickness and fat content in the carcass (ABERLE et al., 1975). This result shows that Texel sheep may be an option for producing low-fat meat, considering new global trends toward consuming foods with lower fat content. In this study, the mean LEA was $14.23 \mathrm{~cm}^{2}$, which is close to the values reported in previous studies, including those of $15.38 \mathrm{~cm}^{2}$ reported by Benaglia et al. (2016) for confined crossbred Suffolk sheep, 13.8 $\mathrm{cm}^{2}$ reported by Cunha et al. (2016) for Pantaneiro sheep, $15.93 \mathrm{~cm}^{2}$ reported by Lima et al. (2013) for Texel sheep, and $15.5 \mathrm{~cm}^{2}$ reported by Urano et al. (2006) for confined Santa Inês sheep. 
The economic viability data (Table 6) calculated herein in relation to feed costs for confined lambs considered only the costs involved with procuring lean lambs (US\$ $2.66 \mathrm{~kg}^{-1}$ of live weight) and feed. The costs (per kg of DM) with feeds containing different levels of coffee husk were very similar (US\$ 0.30 to US\$ 0.27), and decreased with the increased inclusion of coffee husk to replace oat hay. This small reduction occurred because of the high levels of concentrate needed in the feed, which is the costliest component, and thus allowed only reductions of 1 to 3 cents to be generated. Likewise,
Zarpelon et al (2015), also using byproducts in lamb feed, reported a reduction in the cost of dry matter $(\mathrm{kg})$ as corn was replaced with soybean husk.

Even with this modest change in the costs per $\mathrm{kg}$ of feed, the actual profit results (gross margin per kg of carcass) highlighted the benefits of the use of $0.075 \mathrm{~kg} \mathrm{~kg}^{-1}$ of coffee husk to replace hay, as this achieved profits of US\$ 3.25 per $\mathrm{kg}$ of carcass. This profit was higher by 10 and $23 \%$ in relation to the inclusion of 0.15 and $0.225 \mathrm{~kg} \mathrm{~kg}^{-1}$ of coffee husk, respectively, and was $8 \%$ higher than that of the treatment without coffee husk.

Table 6. Economic viability of using coffee husk to replace oat hay in confined finishing lamb feed.

\begin{tabular}{|c|c|c|c|c|}
\hline & \multicolumn{4}{|c|}{ Coffee husk replacing oat hay $(\%)$} \\
\hline & T 0 & T 7.5 & T 15 & T 22.5 \\
\hline Initial live weight (kg) & 22.7 & 22.8 & 23.3 & 23.2 \\
\hline${ }^{1}$ Lean animal cost US $\$ 2.66 \mathrm{~kg}^{-1}$ & 60.38 & 60.38 & 61.97 & 61.71 \\
\hline${ }^{2}$ Total diet cost, US $\$ \mathrm{~kg}^{-1}$ & 0.30 & 0.29 & 0.28 & 0.27 \\
\hline${ }^{3}$ Food cost, US\$ animal ${ }^{-1}$ & 14.71 & 14.22 & 13.35 & 12.75 \\
\hline${ }^{4}$ Total cost (animal plus diet) US\$ animal ${ }^{-1}$ & 75.09 & 74.6 & 75.32 & 74.46 \\
\hline${ }^{5}$ Carcass weight $\mathrm{kg}$ & 15.0 & 15.7 & 14.7 & 13.5 \\
\hline${ }^{6}$ Cost per $\mathrm{kg}$ of carcass, US\$ $\mathrm{kg}^{-1}$ of carcass & 5.01 & 4.75 & 5.12 & 5.52 \\
\hline${ }^{7}$ Confinement gross revenue, US\$ animal ${ }^{-1}$ & 120 & 125.6 & 117.6 & 108 \\
\hline${ }^{8} \mathrm{Gross}$ revenue per $\mathrm{kg}$ of carcass, US $\$ \mathrm{~kg}^{-1}$ of carcass & 8.00 & 8.00 & 8.00 & 8.00 \\
\hline${ }^{9}$ Gross margin per animal, US\$ animal ${ }^{-1}$ & 44.91 & 51 & 42.28 & 33.54 \\
\hline${ }^{10} \mathrm{Gross}$ margin per $\mathrm{kg}$ of carcass, US $\$ \mathrm{~kg}^{-1}$ of carcass & 2.99 & 3.25 & 2.88 & 2.48 \\
\hline
\end{tabular}

* T 0, control diet; T 7.5, 7.5\% coffee husk replacing hay in total DM; T 15, 15\% coffee husk replacing hay in total DM; $\mathrm{T} 22.5$, $22.5 \%$ coffee husk replacing hay in total DM. ${ }^{1}$ Initial animal weight $\mathrm{x}$ cost per $\mathrm{kg}$ of live weight; ${ }^{2} \operatorname{cost}$ per $\mathrm{kg}$ of ingredient in total diet; ${ }^{3}$ total cost of diet per animal; ${ }^{4}$ sum of food cost (3) and animal cost (1); ${ }^{5}$ mean carcass weight per animal; ${ }^{6}$ total cost (4) divided by carcass weight (5); ${ }^{7}$ mean carcass weight multiplied by sales value of the carcass (US\$ $\left.8.00 \mathrm{~kg}^{-1}\right)$; ${ }^{8}$ gross revenue (7) divided by carcass weight (5); ${ }^{9}$ gross revenue per animal (7) minus total cost (4); ${ }^{10}$ gross revenue (8) minus cost per kg of carcass (6).

\section{Conclusion}

Coffee husk can be used at levels of 7.5 to $22.5 \%$ of total dry matter, replacing oat hay in the diet of finishing lambs, to produce animals and carcasses with satisfactory performance levels.

\section{Acknowledgments}

We thank the Coordination for the Improvement of Higher Education Personnel (CAPES) for the Graduate Support Program for Private Educational Institutions (PROSUP) grant.

\section{References}

ABERLE, E. D.; JUDGE, M. D.; MERKEL, R. A.; GERRARD, D. E.; FORREST, J. C.; HEDRICK, H. B.; MILLS, E. W. Principles of meat science. San Francisco: W. H. Freeman Publishers, 1975. 417 p. 
ALMEIDA, J. C. S.; FIGUEIREDO, D. M.; BOARI, C. A.; PAIXÃO, M. L.; SENA, J. A. B.; BARBOSA; J. L.; ORTÊNCIO, M. O.; MOREIRA, K. F. Desempenho, medidas corporais, rendimentos de carcaça e cortes, e qualidade de carne em cordeiros alimentados com resíduos da agroindústria processadora de frutas. Semina: Ciências Agrárias, Londrina, v. 36, n. 1, p. 541-556, 2015. DOI: $10.5433 / 1679-0359.2015 \mathrm{v} 36 \mathrm{n} 1 \mathrm{p} 541$

ASSOCIAÇÃO BRASILEIRA DA INDÚSTRIA DE CAFÉ - ABIC. Indicadores da indústria de café no Brasil. Rio de Janeiro: Ed. Tempo de comunicação, 2018. Disponível em: http://www.abic.com.br/ publique/cgi/ cgilua.exe/sys/ start.htm?sid=61\#5103. Acesso em: 3 jul. 2018.

BENAGLIA, B. B.; MORAIS, M. G.; OLIVEIRA, E. R.; COMPARIN, M. A. S.; BONIN, M. N.; FEIJÓ, G. L. D.; RIBEIRO, C. B.; SOUZA, A. R. D. L.; ROCHA, D. T.; FERNANDES, H. J. Características quantitativas e qualitativas da carcaça e da carne de cordeiros alimentados com torta de girassol. Revista Brasileira de Saúde e Produção Animal, Salvador, v. 17, n. 2, p. 222236, 2016.

CAÑEQUE, V.; SAÑUDO, C. Metodologia para el studio de la calidad de la canal y de la carne en ruminantes. Madrid: INIA, 2000. 254 p.

CAPPELLE, E. R.; VALADARES FILHO, S. C.; SILVA, J. F. C.; CECON, P. R. Estimativas do valor energético a partir de características químicas e bromatológicas dos alimentos. Revista Brasileira de Zootecnia, Viçosa, MG, v. 30 , n. 6, p. 1837-1856, 2001. DOI: 10.1590/S151635982001000700025

CARVALHO, S.; BROCHIER, M. A.; PIVATO, J.; VERGUEIRO, A.; TEIXEIRA, R. C.; KIELING, R. Desempenho e avaliação econômica da alimentação de cordeiros confinados com dietas contendo diferentes relações volumoso:concentrado. Ciência Rural, Santa Maria, v. 37, n. 5, p. 1411-1417, 2007.

CARVALHO, S.; VERGUEIRO, A.; KIELING, R.; TEIXEIRA, R. C.; PIVATO, J.; VIERO, R.; CRUZ, A. N. Desempenho e características de carcaça de cordeiros das raças Texel, Suffolk e cruza Texel x Suffolk. Ciência Rural, Santa Maria, v. 35, n. 5, p. 1155-1160, 2005.

CEZAR, M. F.; SOUZA, W. H. Carcaças ovinas e caprinas: obtenção, avaliação e classificação. Uberaba: Editora Agropecuária Tropical, 2007. 232 p.

CUNHA, C. M.; CORNÉLIO, T. C.; FERNANDES, A. R. M.; SENO, L. O.; RICARDO, H. A.; OSÓRIO, J. C. S.; OSÓRIO, M. T. M.; ALVES, L. G. C.; OLIVEIRA, E. A. Características da carcaça e qualidade da carne de cordeiros Pantaneiros alimentados com teores crescentes de glicerina bruta. Revista Brasileira de Saúde e Produção Animal, Salvador, v. 17, n. 4, p. 729-743, 2016.

CUNHA, M. G. C.; CARVALHO, F. F. R.; GONZAGA NETO, S.; CEZAR, M. F. Características quantitativas de carcaça de ovinos Santa Inês confinados alimentados com rações contendo diferentes níveis de caroço de algodão integral. Revista Brasileira de Zootecnia, Viçosa, MG, v. 37, n. 6, p. 1112-1120, 2008.

DIAS, J. M. C. S.; SOUZA, D. T.; BRAGA, M.; ONOYAMA, M. M.; MIRANDA, C. H. B.; BARBOSA, P. F. D.; ROCHA, J. D. Produção de briquetes e péletes a partir de resíduos agrícolas, agroindustriais e florestais. Brasília: EMBRAPA Agroenergia, 2012. 132 p.

FARIAS, M. S.; PRADO, I. N.; VALERO, M. V.; ZAWADZKI, F.; SILVA, R. R.; EIRAS, C. E.; RIVAROLI, D. C.; LIMA, B. S. Níveis de glicerina para novilhas suplementadas em pastagens: desempenho, ingestão, eficiência alimentar e digestibilidade. Semina: Ciências Agrárias, Londrina, v. 33, n. 3, p. 1177-1188, 2012. DOI: $10.5433 / 1679-0359.2012 v 33 n 3 p 1177$

FISHER, A. V. New approaches to measuring fat in the carcasses of meat animals. In: WOOD, J. D.; FISHER, A. V. (Ed.). Reducing fat in meat animals. London: Elsevier Science Publishers, 1990. p. 255-343.

GARCIA, C. A.; MONTEIRO, A. L. G.; COSTA, C.; NERES, M. A.; ROSA, G. J. M. Medidas objetivas e composição tecidual da carcaça de cordeiros alimentados com diferentes níveis de energia em creep feeding. Revista Brasileira de Zootecnia, Viçosa, MG, v. 32, n. 6, p. 1380-1390, 2003.

GARCIA, I. F. F.; PEREZ, J. R. O.; TEIXEIRA, J. C.; BARBOSA, C. M. P. Desempenho de cordeiros Texel x Bergamácia, Texel x Santa Inês e Santa Inês Puros, terminados em confinamento, alimentados com casca de café como parte da dieta. Revista Brasileira de Zootecnia, Viçosa, MG, v. 29, n. 2, p. 564-572, 2000.

JOHNSON, E. R.; BUTTERFIELD, R. M.; PRYOR, W. J. Studies of fat distribution in the bovine carcass. Australian Journal of Agricultural Research, Melbourne, v. 23, n. 2, p. 381-388, 1972.

LIMA, L. D.; RÊGO, F. C. A.; KOETZ JUNIOR, C.; RIBEIRO, E. L. A.; CONSTANTINO, C.; BELAN, L.; GASPARINE, M. J.; SANCHEZ, A. F.; ZUNDT, M. Interferência da dieta de alto grão sobre as características da carcaça e carne de cordeiros Texel. Semina: Ciências Agrárias, Londrina, v. 34, n. 6, p. 4053-4064, 2013. DOI: 10.5433/1679-0359.2013v34n6Supl2p4053

MACEDO, F. A. F.; SIQUEIRA, E. R.; MARTINS, E. N.; MACEDO, R. M. G. Qualidade de carcaças de cordeiros Corriedale, Bergamácia x Corriedale e 
Hampshire Down x Corriedale, terminados em pastagem e confinamento. Revista Brasileira de Zootecnia, Viçosa, MG, v. 29, n. 5, p. 1520-1527, 2000. DOI: 10.1590/ S1516-35982000000500034

MIZUBUTI, I. Y.; PINTO, A. P.; PEREIRA, E. S.; RAMOS, B. M. O. Métodos laboratoriais de avaliação de alimentos para animais. Londrina: EDUEL, 2009. $228 \mathrm{p}$.

NATIONAL RESEARCH COUNCIL - NRC. Nutrient requirements of small ruminants: sheep, goats, cervids and new world camelids. Washington: National Academy Press, 2007. 384 p.

OLIVEIRA, J. P. F.; FERREIRA, M. A.; FREITAS, A. P. D.; URBANO, S. A.; SILVA, A. E. M. Características de carcaça de ovinos Santa Inês alimentados com mazoferm substituindo o farelo de soja. Revista Ciência Agronômica, Fortaleza, v. 48, n. 4, p. 708-715, 2017. DOI: $10.5935 / 1806-6690.20170082$

OSÓRIO, J. C. S.; OSÓRIO, M. T. M. Produção de carne ovina: técnicas de avaliação in vivo e na carcaça. Pelotas: UFPEL, 2005. 82 p.

OSÓRIO, J. C. S.; OSÓRIO, M. T. M.; VARGAS JÚNIOR, F. M.; FERNANDES, A. R. M.; ALVES, L. G. C. Critérios para abate de ruminantes e a qualidade da carne. In: II SIMPÓSIO BRASILEIRO DE PRODUÇÃO DE RUMINANTES, 2013, Itapetinga. Anais... Itapetinga: UESB, 2013. p. 107-126.

PIRES, C. C.; GALVANI, D. B.; CARVALHO, S.; CARDOSO, A. R.; GASPERIN, B. G. Características da carcaça de cordeiros alimentados com dietas contendo diferentes níveis de fibra em detergente neutro. Revista Brasileira de Zootecnia, Viçosa, MG, v. 35, n. 5, p. 20582065, 2006.

SAÑUDO, C.; PIEDRAFITA, J.; SIERRA, I. Estudio de la calidad de la canal y de la carne en animales cruzados Romanov por Rasa Aragonesa. Comparación en el tipo comercial ternasco com Rasa en pureza. In: JORNADAS CIENTÍFICAS DE LA SOCIEDAD ESPAÑOLA DE
OVINOTECNIA, 7., 1981, Zaragoza. Talavera de la Reina. Actas... Zaragoza. 1981. p. 483-489.

SILVA SOBRINHO, A. G. Aspectos quantitativos e qualitativos da produção de carne ovina. In: PRODUÇÃO ANIMAL NA VISÃO DOS BRASILEIROS, 2001, Piracicaba. Anais... Piracicaba: FEALQ, 2001. p. 425446.

SILVA SOBRINHO, A. G.; OSÓRIO, J. C. S. Aspectos quantitativos da produção de carne ovina. In: SILVA SOBRINHO, A. G.; SAÑUDO, C.; OSÓRIO, J. C. S.; ARRIBAS, M. de M. C.; OSORIO, M. T. M. Produção de carne ovina. Jaboticabal: Funep, 2008. p. 1-68.

SILVA SOBRINHO, A. G.; PURCHAS, R. W.; KADIM, I. T.; YAMAMOTO, S. M. Musculosidade e composição da perna de ovinos de diferentes genótipos e idades de abate. Pesquisa Agropecuária Brasileira, Brasília, v. 40, n. 11, p. 1129-1134, 2005.

SOUZA, A. L. S.; GARCIA, R.; BERNARDINO, F. S.; ROCHA, F. C.; VALADARES FILHO, S. C.; PEREIRA, O. G.; PIRES, A. J. V. Casca de café em dietas de carneiros: consumo e digestibilidade. Revista Brasileira de Zootecnia, Viçosa, MG, v. 33, n. 6, p. 2170-2176, 2004.

URANO, F. S.; PIRES, A. V.; SUSIN, I.; MENDES, C. Q.; RODRIGUES, G. H.; ARAÚJO, R. C.; MATTOS, W. R. S. Desempenho e características da carcaça de cordeiros confinados alimentados com grãos de soja. Pesquisa Agropecuária Brasileira, Brasília, v. 41, n. 10, p. 1525-1530, 2006.

ZARPELON, G.; MIZUBUTI, I. Y.; RIBEIRO, E. L. A.; PEREIRA, E. S.; SILVA, L. D. F.; PRADO-CALIXTO, O. P.; TARSITANO, M. A.; FÁVERO, R.; PIRES, C. A.; BORGES, C. A. A. Desempenho, características de carcaça e avaliação econômica da substituição do milho grão inteiro por casca de soja peletizada na alimentação de cordeiros em confinamento. Semina: Ciências Agrárias, Londrina, v. 36, n. 2, p. 1111-1121, 2015. DOI: $10.5433 / 1679-0359.2015 \mathrm{v} 36 \mathrm{n} 2 \mathrm{p} 1111$ 